\title{
Nietzsche e o Valor: Florescimento e Excelência"
}

\author{
Simon Robertson**
}

\begin{abstract}
Resumo: Florescimento e excelência são dois ideais que ocupam um lugar central no perfeccionismo de Nietzsche. Este artigo procura oferecer uma interpretação original acerca do que está envolvido nestes termos, de como eles se diferenciam e se conectam, desenvolvendo assim um quadro axiológico que confira sentido a esse conjunto. Uma sugestão adicional é de que o modelo subjacente de valor que emerge a partir desta interpretação - com efeito, um modelo de uma vida boa - seja interessante e atrativo por si só, e que, portanto, possa ter um apelo filosófico mais amplo.

Palavras-chave: excelência - perfeccionismo - florescimento - valor
\end{abstract}

\section{Nietzsche demonstra um interesse profundo e pervasivo por um tema central à investigação ética: o que constitui uma vida boa .}

\footnotetext{
* Este artigo é uma versão abreviada de material mais bem desenvolvido na parte III de Robertson (no prelo, especialmente cap. 10). Lá procuro antecipar e responder a uma série de desconfortos teóricos e interpretativos. Farei referência a alguns deles conforme avançamos, mas falta espaço para tratar de todos eles aqui de forma exaustiva. Apresentei materiais relacionados com esta versão do artigo no workshop Practical Agency and Values (Universidade de Warwick, 2013), no congresso Post-Kantian Perfeccionism (Universidade de Sheffield, 2014) e no congresso Nietzsche and Morals (Universidade Federal de Minas Gerais, Belo Horizonte e Ouro Preto, 2014). Muito obrigado aos seus organizadores e à audiência pelas proveitosas discussões - especialmente Ulrike Heuer, David James, Jan Kandiyali, Rogério Lopes, Alexander Nehamas, Peter Poellner, Bernard Reginster, Leonardo Ribeiro, John Richardson, John Skorupski, Dariush Sokolov, and Christoph Schuringa. Tradução de Oscar Augusto Rocha Santos. Revisão técnica de Rogério Lopes.

** Professor de Filosofia na Cardiff University, País de Gales.

Correio eletrônico: robertsons3@cardiff.ac.uk.
} 
Robertson, R.

Seu interesse, em última análise, não é por uma vida simplesmente boa, mas pela excelência. Na verdade, ele desenvolve uma forma de perfeccionismo: um ideal que valoriza, acima de tudo, as mais elevadas excelências humanas. Até agora nada foi dito de enseje contestação. De maneira mais controversa, irei sugerir que seu perfeccionismo combina dois ideais de duas tradições perfeccionistas distintas. Uma delas se concentra na noção de florescimento: quão bem configurada internamente é uma pessoa e quão bem ela se sai em relação ao seu ambiente. A outra nas excelências externas: realizações que, por direito próprio, incorporam algo grandioso ou excelente, exterior ou além do florescimento - poderíamos pensar aqui em realizações artísticas, intelectuais ou culturais, para nos servirmos do estoque de exemplos do próprio Nietzsche. Ambas são formas da excelência. Por razões de clareza, no entanto, e por falta de um termo melhor, usarei daqui em diante o termo "excelência" para denotar exclusivamente as excelências externas distintas do florescimento.

Por que isso tem alguma importância? Em um nível interpretativo, diferenciar esses dois bens é importante para o adequado entendimento da ética de Nietzsche. Os melhores exemplares humanos - "os tipos superiores", como ele frequentemente os chama - florescem [flourish] e se sobressaem [excel]. No entanto, até onde sei, ninguém explicou ainda como exatamente esses dois aspectos se diferenciam ou de fato se conectam. Muitos comentadores focam apenas num ou noutro, isso quando não se movem desconfortavelmente entre um e outro. Agir de tal modo gera algumas dificuldades teóricas e interpretativas. Um dos meus objetivos, portanto, é esclarecer o que o florescimento e a excelência implicam na visão de Nietzsche, e como estes termos se diferenciam e se conectam, desenvolvendo assim um quadro axiológico que confira sentido a esse conjunto. Minha esperança adicional é de que o modelo subjacente de valor que emerge desta exposição - com efeito, um modelo de uma vida boa - é interessante e atrativo por si só, e que, portanto, pode ter 
um maior apelo filosófico.

A exposição está organizada da seguinte maneira. 0 §1 faz três breves observações a respeito da abordagem do artigo. §§2-4 examinam o florescimento: seus componentes básicos, como eles se ajustam e seu valor. $\$ 5$-6 se voltam para a excelência e seu valor. O $\S 7$ conclui com algumas breves considerações sobre o apelo filosófico mais amplo do que foi exposto.

\section{Três considerações preliminares}

Primeiramente, meu foco aqui é o valor: aquela esfera de pensamento que reúne asserções articuláveis por meio de conceitos valóricos como bom, mau, melhor e pior. Estou tratando a esfera valorativa como distinta daquele aspecto do domínio normativo, focado no que as pessoas devem e têm razão em fazer. Particularmente, asserções na forma "seria bom A fazer $\phi$ " não ocasionam uniformemente asserções na forma "há uma razão para A fazer $\phi$ ". ${ }^{1}$ Isso é importante para Nietzsche em vários aspectos. Mencionarei aqui um. Suponha que, para A fazer $\phi$, A tenha que alcançar um fim $E$ que inclui certa excelência altamente valorosa, mas A é irremediavelmente medíocre e completamente incapaz de fazer $\phi$ ou de realizar $E$. Neste caso, não deve haver razão para A fazer $\phi$ ou buscar $E$. Enquanto as verdadeiras asserções práticas de "dever" e "razão" implicam "poder", o mesmo não vale necessariamente para asserções genuinamente valorativas. ${ }^{2}$

Em segundo lugar, o modelo proposto envolve inevitavelmente alguma reconstrução. Os componentes básicos que lhe dão forma são sustentados por evidência textual e cada um tem um pedigree

1 Onde 'A' representa um agente e ' $\phi$ ' é um verbo particípio denotando um símbolo de ação.

2 Examino a concepção nietzschiana de normatividade em outro lugar. (Cf. ROBERTSON, Simon. "Normativity for Nietzschean Free Spirits". In. Inquiry 54(6), 2011, p. 591-613). Não pretendo, contudo, separar inteiramente os domínios normativo e valorativo; sobre o modo como esses domínios se conectam (Cf. ROBERTSON, Simon Nietzsche \& Contemporary Ethics. Oxford University Press, cap. 11). 
Robertson, R.

interpretativo estabelecido; o principal trabalho de reconstrução envolve encaixar esses componentes. Isso implica uma combinação de considerações textuais e filosóficas: traçar distinções que talvez estejam de forma meramente implícita nos próprios escritos de Nietzsche e desenvolver um quadro axiológico exequível. Uma virtude da descrição resultante é que ela reconcilia o que de outra forma poderia passar por posições conflituosas no pensamento de Nietzsche.

Por último, como já foi mencionado, um aspecto central deste modelo é a existência de dois bens fundamentais, mas nem sempre claramente distintos: florescimento e excelência. Explicarei isso em parte pelos modos como são exemplificados pelos "tipos superiores". Tais tipos desempenham dois papéis. Por um lado, eles são os poucos e raros que alcançam a plena grandeza através do florescimento $e$ da realização de excelências externas. Isso é uma tese constitutiva acerca do que significa ser um tipo superior em sentido pleno. Recorro a tais tipos para revelar o ideal perfeccionista de Nietzsche. Por outro lado, estou me servindo deles também como de um dispositivo retórico: com o intuito de elucidar características mais gerais da estrutura e do conteúdo de uma vida boa - características que, assim espero, se combinem para fornecer um modelo que possa ter apelo mesmo para aqueles que querem resistir aos excessos mais bombásticos que caracterizam a própria posição de Nietzsche.

\section{Florescimento: componentes substantivos}

Existem várias palavras alemãs aptas a traduzir "florescimento", incluindo "Gedeihen" e "Aufblühen". Nietzsche usa esses termos de forma relativamente econômica em seus trabalhos publicados. ${ }^{3}$

3 Cf. WB/Co. Ext. IV 11, KSA 1.506; FW/CG 347, KSA 3.581; GM/GM, Prólogo, 3, II, 10, 12 , III 11, 19, KSA 5.249, 308, 3113, 361, 384; EH/EH, Prólogo, 2, Por que sou um destino 7, KSA $6.257,371$.

148 | Cad. Nietzsche, Guarulhos/Porto Seguro, v.37 n.1, p. 145-184, 2016. 
De todo modo, muito do que ele escreve sobre saúde [Gesundheit] - seja quando se refere aos seres humanos enquanto indivíduos ou enquanto espécie, seja quando a questão se situa em um nível psicológico, fisiológico ou social - está de acordo com o que nós mais habitualmente pensamos comoflorescimento. Concentro-me aqui no indivíduo. Florescimento e saúde estão também inextrincavelmente atados à enigmática máxima nietzschiana de tornar-se o que se é (FW/GC 270, 335, KSA 3.519, 560). ${ }^{4}$ Tal "tornar-se si mesmo" é um processo em andamento que requer realizar ativamente seu mais elevado potencial. Você está em um processo de florescimento apenas quando suas atividades promovem seu (mais elevado) potencial; e você pode alcançar um estado de florescimento por meio da realização desse potencial. No entanto, o florescimento, enquanto processo ou estado, uma vez alcançado, não é permanente. Ele pode se desenvolver ou se deteriorar dependendo do que você faz, é algo que se dá em graus: o grau no qual você floresce, tanto no tempo quanto ao longo de sua vida, depende (inter alia) da medida em que você realiza seu potencial.

Nietzsche enfatiza dois conjuntos gerais de condições que um agente humano que floresce satisfaz: o que podemos chamar de eficácia psicológica e ser um agente efetivo. ${ }^{5}$ Estas condições estão

4. Genealogia da Moral e Ecce Homo são particularmente abundantes em falas sobre saúde, com o subtítulo de EH 'como se tornar o que é' sugerindo uma conexão não coincidente entre saúde e tornar-se si mesmo. A ideia de florescimento é bastante comum na literatura secundária; veja, por exemplo, LEITER, Brian. "Nietzsche's Metaethics: Against the privilege Readings. In. European Journal of Philosophy 8 (3), 2000, p. 277-297.

5 As condições psicológicas são enfatizadas, por exemplo: (GEMES, Ken. "Freud and Nietzsche on Sublimation”. In. Journal of Nietzsche Studies 38 (1), 2009, p. 38-59); (JANAWAY, Christopher. "Nietzsche on Morality, Drives, and Human Greatness". In. JANAWAY, C. \& ROBERTSON, S. (Org.). Nietzsche, Naturalism and Normativity. Oxford: Oxford University Press, 2012, p. 183-201); agência efetiva: (CLARK, Maudemarie. "On the Rejection of Morality: Bernard Williams' Debt to Nietzsche”. In. SCHACHT, R. (Org.). Nietzsche's Postmoralism Cambridge: Cambridge University Press, 2001, p. 100-122); (REGINSTER, Bernard. "The Will to Power and the Ethics of Creativity". In. LEITER, B. \& SINHABABU, N. (Org.) Nietzsche and Morality. Oxford: Clarendon Press, 2007, p. 32-56); (OWEN, David. Nietzsche's Genealogy of Morality. 
Robertson, R.

interligadas: o florescimento envolve um entrosamento adequado entre seu perfil psicológico e o que você faz. Para esclarecer melhor esse ponto, irei apresentar esquematicamente mais quatro elementos específicos.

Primeiramente, tornar-se o que se é por meio da realização do seu mais elevado potencial envolve autocompreensão ${ }^{6}$. Seu potencial, ou o que você faz de você mesmo e, portanto, o que você se torna, é, sob vários aspectos, moldado e constrangido por quem você já é. Assim, para entender o que você pode se tornar, você precisa entender quem você já é. Para Nietzsche, o que faz de você a pessoa particular que você é depende significativamente de fatos psicológicos sobre você - incluindo suas capacidades cognitivas e afetivas, habilidades, limitações e propensões. Um item central desta classe de fatos psicológicos são o que podemos chamar seus "motivos": qualquer item psicológico que motiva ou que possa motivar você. Nietzsche distingue uma variedade de tais motivos: impulsos, afetos e instintos, mas também desejos, paixões, sentimentos, gostos, compromissos avaliativos etc. (Assim como nos motiva diretamente, os motivos frequentemente desempenham uma série de papéis em segundo plano; juntos, eles produzem disposições gerais de caráter e de avaliação, moldando assim o tipo de pessoas que somos e o tipo de coisas que somos motivados a fazer). Assim, parte do que constitui uma pessoa, como o indivíduo particular que é, são seus motivos e o modo como estes são configurados, isto é, sua "hierarquia" e as relações hierárquicas entre eles (JGB/BM 219, 268, KSA 5.154, 221). A autocompreensão, portanto, implica uma compreensão das particularidades de quem somos, na medida em que estas estão

Acumen Press, 2007); (RIDLEY, Aaron. "Nietzsche's Intentions: What the Sovereign Individual Promises". In. K. GEMES \& S. MAY (Org.). Nietzsche on Freedom and Autonomy. Oxford: Oxford University Press, 2009).

6 Veja, por exemplo, as exaltações de Nietzsche ao "conhece-te a ti mesmo": $F W / G C 335$, KSA 3.560; JGB/BM 39, KSA 5.56; AC/AC 50, KSA 6.229; EH/EH, Por que sou um destino 7 , KSA 6.371.

$150 \mid$ Cad. Nietzsche, Guarulhos/Porto Seguro, v.37 n.1, p. 145-184, 2016. 
incorporadas a (inter alia) nossos motivos. ${ }^{7}$ Esta pode ser uma tarefa exigente. Muitos de nossos motivos operam em níveis não-conscientes, fazendo surgir uma interação complexa de forças motivacionais competindo para se expressar, inclusive por meio da inibição e da sabotagem mútua, de maneiras que não nos são imediatamente transparentes ${ }^{\mathbf{8}}$. A autocompreensão requer, portanto, um escrutínio inflexivelmente honesto de si mesmo9: avaliação verídica do tipo de pessoa que se é - "examinar todas as forças e fraquezas de [sua] natureza" (FW/GC 290, KSA 3.530; cf. $F W / G C$ 335, KSA 3.560) incluindo a interação dos motivos que fazem com que alguém seja quem ele é.

O segundo componente é o "autodomínio". Isso envolve ordenar e direcionar os motivos como um todo coerente - tendo os pros e contras em seu poder e impondo a eles uma "hierarquia" (Cf. MA I/ HH I, Prólogo 6, KSA 2.20; GM/GM, III, 12, KSA 3.563). ${ }^{10}$ Nietzsche pensa que ao menos alguns indivíduos são constituídos por uma multiplicidade de motivos diversos e conflitantes. Para que floresça, tal indivíduo deve dominar e ordenar essa multiplicidade de motivos

7 Para maiores detalhes em relação aos motivos e seus papeis no pensamento de Nietzsche, ver Robertson (Normativity for Nietzschean Free Spirits, Op. Cit.) e (no prelo, Cap. 8). Leiter (Op. cit, p. 101-104) interpreta Nietzsche como um autor que reivindica que nós nunca sabemos (ou por implicação, entendemos) nossos motivos. Uma preocupação diferente acerca do papel que eu dei à autocompreensão baseia-se na sugestão de Nietzsche em Ecce Homo (Cf. EH/EH, Por que sou tão esperto 9, KSA 6.293) de que "se tornar o que você é pressupõe que você não tem a mais vaga ideia do que você é". Trato dessas duas questões de interpretação em Robertson (no prelo, Cap. 10).

8 Cf. $M / A$ 119, 129, KSA 3.111, 118; JGB/BM 200, KSA 5.120; GD/CI, Incursões de um extemporâneo 49, KSA 6.151; Nachlass/FP 27 [59], KSA 11.289.

9 Cf. $F W / G C$ 335, KSA 3.560; JGB/BM 39, KSA 5.56; AC/AC 50, KSA 6.229; EH/EH, Por que sou um destino 7, KSA 6.371.

10 Para uma discussão mais detalhada, ver ANDERSON, Lanier R. "What is a Nietzschean Self?". In. JANAWAY, C. \& ROBERTSON, S. Nietzsche, Naturalism and Normativity. Oxford: Oxford University Press, 2012, p. 202-35; JANAWAY, Christopher. "Nietzsche on Morality, Drives, and Human Greatness". In. JANAWAY, C. \& ROBERTSON, S. (Org.). Nietzsche, Naturalism and Normativity. Oxford: Oxford University Press, 2012, p. 183-201. 
Robertson, R.

em um todo mais ou menos coeso - para que eles não façam dele uma bagunça psicologicamente des-integrada. Existem diversos modos de se alcançar tal unidade e autodomínio. Nietzsche supõe que essa unidade surge quando os motivos são estruturados hierarquicamente sob um conjunto dirigente de impulsos. Mas ao invés de extirpar ou apaziguar diretamente os motivos recalcitrantes em relação ao conjunto de impulsos dirigentes, estas figuras que ele enaltece os sublimam. Eles são redirecionados sem serem enfraquecidos, de modo que sua energia é aproveitada em um todo unificado que herda sua força combinada ${ }^{11}$. Quanto mais forte for a combinação dos impulsos, mais veemente é a necessidade de se expressarem por meio de ações e é tanto mais provável que eles venham a se expressar desse modo. Assim, as atividades de tal pessoa extravasam um "sentimento de plenitude" e "abundância de poder" (JGB/BM 260, KSA 5.208). O ideal de Nietzsche é, então, o de uma energia psíquica intensificada, obtida por meio da unidade-na-diversidade; o que conduz melhor à atividade.

Autocompreensão e autodomínio não são suficientes para o florescimento nietzschiano, mas favorecem os outros dois elementos. O terceiro envolve estabelecer para si mesmo objetivos, cuja busca e realização expressariam quem você é. O florescimento implica atividade; isto é, fazer coisas; mas ele exige também fazer coisas que expressam quem você é. E isso requer estabelecer objetivos que permitam tal expressão. Nós podemos destrinchar proveitosamente mais dois componentes subsidiários. Primeiramente, Nietzsche enfatiza a importância de determinar seus próprios objetivos (e para você mesmo); segundo, você tem de estabelecer para você mesmo objetivos apropriados. (Estes representam ideais de autonomia e autenticidade). Os objetivos que você de fato estabelece para você mesmo serão moldados e constrangidos por seus motivos existentes; e

11 Cf. M/A 109, KSA 3.96JGB/BM 200, KSA 5.120; GD/CI, Incursões de um extemporâneo 49, KSA 6.151; Nachlass/FP 27 [59], KSA 11.289.

152 | Cad. Nietzsche, Guarulhos/Porto Seguro, v.37 n.1, p. 145-184, 2016. 
qualquer coisa que você faz irá, de uma maneira ou de outra, refletir seu conjunto motivacional antecedente. ${ }^{12}$ Mas pode haver modos mais ou menos apropriados (ou modos melhores e piores) para você se expressar, de acordo com quem você é. Nietzsche algumas vezes sugere que você tem de compreender quem você é para que possa estabelecer para si mesmo objetivos apropriados que lhe darão a possibilidade de melhor expressar quem você é (daí a importância que ele confere à autocompreensão). Neste caso, seus objetivos devem refletir uma atenção verídica a quem você já é $e$ uma apreciação realística de seu potencial futuro: realística no sentido de que sua avaliação daquilo que conta como uma possibilidade prática genuína deve ser sensível aos fatos acerca do tipo de pessoa que você já é, incluindo seus motivos e habilidades, na medida em que estes fatos moldam e constrangem as potencialidades que você poderia efetivar e, portanto, aquilo que é capaz de fazer de si ou de se tornar. O que, entretanto, explica o fato de que ordenar e direcionar seus motivos de um modo seria mais apropriado do que de outro? - por que priorizar a expressão desses motivos particulares e direcionar sua atividade justamente àqueles objetivos em vez de outros? Em suma, os motivos e objetivos a priorizar são aqueles que melhor permitam a você expressar-se como um agente. De maneira mais informativa, agir à luz de certos motivos e objetivos será mais vantajoso à atividade continuada de longo prazo que você considera significativa na medida em que ela te torna pleno [it fulfils you]. ${ }^{13}$ Por um lado, se você tem um impulso criativo profundamente enraizado, por exemplo, de forma geral será vantajoso ao seu florescimento que você estabeleça para você mesmo objetivos que lhe permitam expressar-se criativamente,

12 Ver ROBERTSON (no prelo), op. cit., p. 597-599; também KATSAFANAS, Paul. Agency and the Foundations of Ethics: Nietzschean Constitutivism. Oxford: Oxford University Press, 2013, Cap. 5.

13 Dadas estas duas variáveis - atividade continuada e que te faz pleno - a adequação dos objetivos que você estabelece para si mesmo não é reduzida a uma função (neo-Humeana) da força ou dominação de certos motivos sobre outros. 
Robertson, R.

porque expressar-se através de atividades criativas com as quais você se importa será significativo e terá mais probabilidade de torná-lo pleno. Por outro lado, será mais vantajoso ao seu florescimento (e assim mais apropriado) estabelecer para você mesmo objetivos que favoreçam a atividade continuada - projetos de longo prazo que permitam que você continue a expressar-se de modos que o tornem pleno - ao invés de resoluções curtas ou meramente episódicas. Deste modo, "um grande homem", escreve Nietzsche, tem "uma longa lógica em todas as suas atividades... ele tem a habilidade de estender sua vontade através das grandes extensões de sua vida" (Nachlass/FP 34 [96], KSA 11.451).

Finalmente, em quarto lugar, você deve de fato realizar os objetivos que você estabeleceu para si mesmo de forma apropriada. Parte do pensamento de Nietzsche é que os motivos, enquanto disposições para agir, são como feixes de energia psíquica, procurando se expressar por meio da ação (GM/GM, II, KSA 5.291-337). Quanto mais eles permanecem sem se expressar, mais veementes eles se tornam (a explicação nietzschiana remete ao fato de que somos criaturas orientadas-para-agir, parcialmente compostas por impulsos que precisam se expressar de algum modo - como posto para efeito dramático na explicação da revolta escrava na moral, apresentada na primeira dissertação da Genealogia da moral). Desse modo, ao expressar seus motivos por meio da ação, você satisfaz uma parte importante do que você é: um agente orientado-para-agir. Além disso, no entanto, ao realizar os objetivos que são apropriados a sua realização, você não apenas descarrega motivos que precisam se expressar de algum modo, mas também expressa os motivos constitutivos de quem você é e pelos quais você expressa a si mesmo. Pois nós queremos não apenas agir, mas fazer coisas específicas realizar objetivos particulares, superar os desafios que estabelecemos para nós mesmos, e assim por diante (novamente, quando somos incapazes de nos engajar nessas atividades, ou quando estamos 
presos a projetos que não nos tornam plenos ou não expressam quem somos, é comum nos sentirmos profundamente frustrados, ainda que isso não seja imediatamente transparente a nós). Nós temos uma profunda necessidade psicológica de sermos efetivos não apenas naquilo que de fato fazemos, mas em expressar quem nós somos. Para Nietzsche, ao estabelecer e realizar seus próprios objetivos objetivos que expressam o que você é - você "cria a si mesmo" e realiza seu potencial de "se tornar quem você é" (ou poderia ser). Tal como ele o coloca no contexto de tipos superiores de espírito livre, tais pessoas "querem se tornar quem [eles] são - seres humanos que são novos, únicos, incomparáveis, que dão leis a si mesmos, que criam a si mesmos" (FW/GC 335, KSA 3.560).

Os quatro componentes, tomados conjuntamente, contribuem para uma visão de pessoa que floresce como um agente que governa a si mesmo, autêntico e efetivo. Alguém que tem domínio sobre si mesmo e que determina seus próprios fins; alguém que, através da realização destes fins por meio de agência efetiva, expressa quem ele é de modos que o tornam pleno. ${ }^{14} \mathrm{~A}$ fim de facilitar a referência, irei sumariar as considerações feitas até aqui dizendo que o florescimento nietzschiano envolve:

(1) alcançar um alto grau de eficácia e unidade psicológica (via autocompreensão, autodomínio e estabelecimento dos próprios objetivos de modo soberano ou autônomo), e;

(2) se expressar externamente através de sua agência (realizando seu potencial para se tornar quem você poderia ser por meio da realização dos objetivos que são apropriados estabelecer para você

14 Apresentei os quatro componentes separadamente, como se os três primeiros (autocompreensão, autodomínio e estabelecimento dos próprios objetivos) fossem precondições para uma agência por meio da qual um agente expressa a si mesmo de forma efetiva. Entretanto, estes componentes podem interagir orgânica e dinamicamente. Por exemplo, direcionar suas ações de um modo unificado poderia ser uma maneira de alcançar o autodomínio e a autocompreensão: uma forma de se tornar um agente unificado e de esclarecer quem você realmente é através do que você faz (Ver PIPPIN, Robert. Nietzsche, Psychology, \& First Philosophy. Chicago: Chicago University Press, 2010, Cap. 4; RIDLEY, Aaron. Op. cit.). 
Robertson, R.

mesmo).

Essas observações se encaixam perfeitamente com visões atrativas independentes acerca do que envolve em geral um bem ou o florescimento: integração psicológica (por exemplo, unidade psicológica nascida da autocompreensão e do autodomínio); autonomia (isto é, autodomínio e governo de si manifestados e alcançados através da determinação e busca de seus próprios fins); ser um agente efetivo que alcança os objetivos que você pôs para si mesmo; autoexpressão ou autenticidade (expressar partes importantes de quem é você) alcançada através do engajamento em atividades que você considera significativas e que te tornam pleno; e manter essa atividade ao longo de sua vida. Antes de passar ao valor do florescimento, precisamos considerar de que modo (1) e (2) se conectam estruturalmente.

\section{Florescimento: questões estruturais}

Como um primeiro ponto, dada a ênfase de Nietzsche em sermos criaturas orientadas-para-agir, poderíamos seguramente tratar (2) como uma condição necessária para o florescimento. De fato, é difícil ver como você poderia florescer se você é sistematicamente incapaz de realizar os objetivos que é apropriado que você realize, dado quem você é, e assim falha em se expressar como um agente orientadopara-agir. Na medida em que as várias condições que acompanham (1) são necessárias para (2), elas poderiam também ser vistas como necessárias. É novamente difícil ver como você poderia florescer, a não ser que você possua ou alcance ao menos um bocadinho de eficácia e de unidade psicológica. Há espaço para divergências aqui. De todo modo, irei daqui em diante apenas assumir que satisfazer as condições que acompanham (1), ou ao menos satisfazer certo grupo de tais condições em algum grau necessárias para garantir (2), é também necessário. Assim, assumirei que (1) e (2) são componentes necessários do florescimento nietzschiano. 
Em segundo lugar, para elaborar agora um ponto já implícito, você pode florescer em um grau maior ou menor. Você pode ser psicologicamente unificado em uma maior ou menor extensão. Você pode estabelecer para si mesmo objetivos que, se realizados, expressam seus motivos mais profundos de maneira mais ou menos completa, ou expressam motivos mais ou menos constitutivos de quem você realmente é. Você pode realizar estes objetivos em uma maior ou menor extensão. $E$ você pode florescer em graus maiores ou menores em diferentes períodos da sua vida. É improvável que haja uma linha de corte nítida acima da qual você definitivamente está florescendo e que abaixo não. No entanto, há numerosas maneiras pelas quais você pode falhar em florescer. Pode faltar a você um grau requerido de eficácia ou unidade psicológica. Você poderia selecionar objetivos inapropriados (objetivos que você acaba achando profundamente insatisfatórios, digamos). Ou você poderia fracassar completamente na realização dos objetivos que você estabeleceu para si mesmo. Qualquer um desses fracassos poderia resultar de algo que diz respeito a você (suas inabilidades ou indisciplina, digamos) ou a fatores extrínsecos (incluindo simples má sorte). E algumas pessoas talvez nunca se encontrem nas condições que elas precisariam estar para poderem florescer - se, por exemplo, seu contexto social as afasta completamente da realização dos objetivos que elas precisariam realizar para poderem expressar quem são.

Em terceiro lugar, essa é uma explicação parcialmente substantiva do florescimento. Ela especifica uma série de condições substantivas ou bens: autocompreensão, integração psicológica, autonomia, agência efetiva, autoexpressão etc. Mas ela é também parcialmente formal: ela não especifica quaisquer objetivos ou motivos particulares que uma pessoa necessita ter ou realizar para florescer. Sua realização múltipla, portanto, autoriza uma variação significativa no modo como as diferentes pessoas florescem, o que dependerá do conteúdo dos seus motivos e objetivos. 
Robertson, R.

Em quarto lugar, deveríamos avaliar se a satisfação das condições (1) e (2) é suficiente para o florescimento nietzschiano. Para que isso seja plausível, talvez seja preciso adicionar uma ressalva no sentido de que você realize seus objetivos das maneiras corretas: através da competência, ao invés da total casualidade, que suas atividades estejam relacionadas de modo não acidental com os objetivos que você estabeleceu para si mesmo, e assim por diante. Mas se assumirmos que as conexões corretas estão dadas, ${ }^{\mathbf{1 5}}$ as condições (1) e (2), tomadas conjuntamente, seriam suficientes para o florescimento, pelo menos em certo grau?

Nietzsche pode ter tido visões inconsistentes sobre isso. Por um lado, ele algumas vezes fala de indivíduos e tipos que são "doentes" ou "sem saúde", e sugere que um "pré-requisito" para alcançar um estado real de saúde é 'ser essencialmente saudável' (EH/EH, Por que sou tão sábio, 2, KSA 6.266), isto é, ter uma capacidade ou disposição saudável subjacente. Recorrer à metáfora de uma pessoa saudável para indicar uma pessoa que floresce pode sugerir que alguém que não tenha a capacidade essencial de ser saudável é incapaz de florescer. E Nietzsche (algumas vezes) parece de fato pensar que existem tais pessoas - os "tipos sacerdotais" talvez sejam um exemplo-chave. Assim, assumindo (por ora) que tais tipos sacerdotais poderiam satisfazer (1) e (2), eles seriam, no entanto, incapazes de florescer. Por outro lado, ele parece de todo modo igualmente aceitar que tipos diferentes de pessoas podem florescer de modos diferentes, relativamente ao tipo que são. Ele afirma que "todos os animais [...] lutam instintivamente por uma combinação ótima de condições favoráveis que lhes permitam expandir sua energia e alcançar seu máximo sentimento de poder" (GM/GM, III, 7, KSA 5.349). Além disso, é central à sua crítica da moralidade a tese de que as pessoas são frequentemente capazes de assegurar tais condições com bastante eficiência. Na verdade, tipos sacerdotais

15 Não ficarei repetindo essa ressalva, mas ela pode ser continuamente pressuposta.

158 | Cad. Nietzsche, Guarulhos/Porto Seguro, v.37 n.1, p. 145-184, 2016. 
podem ser extremamente eficientes para alcançar o (sentimento de) poder que almejam, governando o rebanho por meio das instituições morais e religiosas que propagam. ${ }^{16}$ De modo similar, obedecer à moralidade serve aos interesses, necessidades e instintos da maioria medíocre arrebanhada ${ }^{17}$. Do mesmo modo, tipos monstruosos poderiam florescer sendo monstruosos ${ }^{18}$ e os tipos superiores poderiam florescer sobressaindo-se. Em cada caso os indivíduos podem florescer relativamente ao tipo que são, isso segundo o pressuposto de que assegurar as condições necessárias para satisfazer e manter os próprios interesses (necessidades, impulsos por poder etc.) seja geralmente vantajoso ao florescimento que cabe ao tipo que são. Isso permitiria admitir que (1) e (2) são suficientes no final das contas.

Dadas estas tensões evidentes, talvez tenhamos que atribuir a Nietzsche uma visão ou outra. ${ }^{19}$ Irei considerar brevemente duas

16 Portanto, embora algumas vezes Nietzsche descreva os sacerdotes como as pessoas "mais impotentes" (GM/GM, I, 7, KSA 5.266), em outros lugares ele diz que o sacerdote "percebe que a moralidade cristã era seu meio para o poder" (EH/EH, Por que sou um destino, 7, KSA 6.371), que o sacerdote é tanto "doente" quanto "forte", e "ainda mais senhor de si que os outros" (GM/ GM, III 15, KSA 5.372; veja também GM/GM, III, 11, 13, 18 KSA 5.361, 65, 82).

17 Cf. JGB/BM 198, 201, 202, KSA 5.118, 121, 124; GM/GM I, III, KSA 5.257 s. 5.339s.; Nachlass/FP 7 [6], KSA 12.273.

18 Note a ambivalência de Nietzsche em relação a Napoleão: uma "síntese de inumano e superhumano" (GM/GM, I, 16, KSA 5.285; cf. JGB/BM 256, KSA 5.201; KAUFMANN, W. Nietzsche: Philosopher, Psychologist, Antichrist. Princeton: Princeton University Press, 1974, p. 314-316). Na leitura que estou gradualmente desenvolvendo, isso é explicado pela ideia de que Napoleão encontra as condições suficientes para seu florescimento, mas ele fica abaixo da excelência caracterizada pelos tipos superiores em sentido pleno.

19 Poder-se-ia tentar reconciliar estas posições conflitantes através da sugestão de que ele se vale (talvez para propósitos retóricos específicos) de diferentes concepções de florescimento em diferentes contextos: ele algumas vezes concede que, relativamente ao potencial que os tipos sacerdotais têm, eles podem florescer (eles ao menos fazem o tipo de coisas necessárias para sobreviver e prosperar como um tipo sacerdotal); mas eles ficam aquém de certo padrão adicional de florescimento. Talvez não haja problema em adotar diferentes concepções de florescimento para defender diferentes posições. Mas se estamos buscando esclarecer em que consiste o florescimento nietzschiano, isso apenas adia o problema sem resolvê-lo: permanecemos com duas concepções (intensional e extensionalmente) divergentes, persistindo, desse modo, a questão sobre qual delas é preferível. 
Robertson, R.

possíveis razões para negar que (1) e (2) sejam condições suficientes; porém, irei argumentar que estas razões são inconclusivas e na sequência oferecerei duas razões para aceitá-las como condições suficientes.

Uma primeira razão para dúvida é ilustrada pelo seguinte exemplo. Suponha que um artista à frente de seu tempo domine seus motivos e expresse quem ele é por meio da produção de pinturas incríveis, assim satisfazendo (1) e (2). Mas seus pares no mundo da arte zombam, desprezam ou ignoram seus esforços; assim, embora ele continue a produzir uma arte fabulosa, ele nunca recebe o reconhecimento que procura. No entanto, segundo o modelo de suficiência, ele floresce (ao menos em certo grau). Na visão de insuficiência, dado o contexto artístico-social no qual ele se encontra, ele não logra êxito em (e talvez seja incapaz de) florescer. Nesse cenário, suspeito que Nietzsche teria optado pelo resultado implicado pelo modelo de suficiência. Isso na medida em que ele aceita que as pessoas podem florescer ainda que (e parcialmente porque) elas desafiem e superem resistências externas (por exemplo, sociais) aos projetos por meio dos quais elas realizam seu potencial. $\mathrm{Na}$ verdade, esta é a difícil condição de muitos tipos superiores de espírito livre - indivíduos que florescem ao expressar quem são, apesar das resistências extrínsecas que encontram (e apesar de suas conquistas não serem reconhecidas em seu próprio período de vida - na verdade, Nietzsche retrata a si mesmo como alguém "nascido postumamente" (EH/EH, Por que escrevo livros tão bons, 1, KSA 6.298; AC/AC, Prólogo, KSA 6.167). Caso você não esteja persuadido, gostaria de afastar algumas inquietações. A resistência ao modelo de suficiência gerada por esse exemplo provém da seguinte conjunção de ideias: que uma pessoa seja capaz de florescer é algo que deve depender, ao menos em parte, das condições sociais nas quais ela se encontra; e nosso artista poderia florescer de modo bem mais completo em condições sociais diferentes. De todo modo, o modelo 
de suficiência é inteiramente compatível com ambas as ideias. A capacidade de nosso artista de se expressar nos modos necessários para seu florescimento depende da existência de condições sociais que não impeçam completamente sua autoexpressão. Além disso, ele poderia florescer mais plenamente, caso as condições sociais fossem diferentes. De todo modo, aceitar ambos os pontos não implica que, no cenário descrito, ele não floresça de modo algum. Na verdade, ele floresce de forma mais plena por meio da expressão artística de aspectos importantes de quem ele é do que o faria por meio da mera conformidade às expectativas dos outros e sem a expressão de sua criatividade. Assim, é importante enfatizar que o modelo de suficiência implica apenas que se alguém satisfaz (1) e (2), então ele floresce em alguma medida.

Uma segunda possível dúvida surge da reconsideração da variedade das figuras que (conforme sugeri) poderiam, em princípio, satisfazer (1) e (2), mas que são desprezadas por Nietzsche: o tipo de rebanho, os medíocres, os tipos sacerdotais, os monstruosos etc. A mais óbvia base racional para negar que eles florescem é que, mesmo que satisfaçam (1) e (2), eles não logram êxito em realizar as variedades de excelência externa que caracterizam os tipos superiores nietzschianos. Isso agrega ao conceito nietzschiano de florescimento a realização de excelências relevantes. Minha resposta inicial é concordar que tais pessoas não se sobressaem, mas dizer, no entanto, que elas podem florescer (ao menos em certa medida) relativamente aos tipos que são. Ao dominar seus motivos e realizar os objetivos que apropriadamente estabeleceram para si mesmos, de modo que sejam capazes de expressar quem são, elas realizam seu potencial - só que o potencial que possuem não é adequado à realização de excelências externas.

Uma réplica a essa resposta, para ser conclusiva, teria que fornecer razões independentes para negar que pessoas não-excelentes, mesmo satisfazendo (1) e (2), não logram êxito em atingir qualquer 
Robertson, R.

grau de florescimento. Não estou certo de como esse argumento seria válido. ${ }^{20}$ Mas há aqui um modo mais indireto de exercer pressão sobre o espírito do modelo de suficiência. Essa via consiste em negar que pessoas que não são excelentes possam de fato satisfazer (1) e (2); com isso elas não lograriam êxito em florescer. Isso não solaparia o modelo de suficiência, mas lançaria dúvida sobre a implicação que estou extraindo dele: ou seja, que pessoas não-excelentes podem florescer. Assim, é importante considerar esta abordagem. Para fazêlo, irei recorrer brevemente a uma ideia proposta recentemente por Christopher Janaway. ${ }^{21}$ A ideia básica é a seguinte: para satisfazer a concepção nietzschiana de florescimento são necessários impulsos que sejam excepcionalmente fortes e ao mesmo tempo diversos e unificados; essa é uma característica marcante dos grandes indivíduos criativos, mas que está ausente nos indivíduos que não são excelentes - é improvável, por exemplo, que os contadores de grama de Rawls tenham impulsos particularmente fortes ou diversos; portanto, apenas os excelentes satisfazem a condição (1).

Vamos conceder que alguém com impulsos excepcionalmente veementes, diversos-porém-unificados, seja mais propenso a ser um indivíduo criativo e de vontade forte do tipo que Nietzsche exalta. De todo modo, é difícil ver por que tipos sacerdotais, ou contadores de grama etc., não poderiam igualmente satisfazer tais condições, ainda que deste modo eles expressem quem são através da realização de

20 Suspeito ainda que negar que pessoas não excelentes possam florescer em algum grau, somente porque elas não logram êxito em realizar excelências externas, torna a disputa em grande parte terminológica: o modelo de suficiência afirma que eles podem florescer, enquanto o modelo de insuficiência implica que, ao invés disso, eles "inflorescem". Uma motivação "ideológica" por trás do modelo de suficiência é a seguinte: se Nietzsche há de ser de amplo interesse filosófico nessa questão, faríamos melhor em atribuir a ele uma concepção mais inclusiva de florescimento.

21 JANAWAY, Christopher, op. cit., p. 186-192. (Veja também RICHARDSON, John. Nietzsche’s system. Oxford: Oxford University Press, 1996; GEMES, Ken. Op. Cit.) O foco oficial de Janaway é uma ideia levemente diferente que ele denomina "grandeza" nietzschiana. Mas ele concorda que a grandeza envolve encontrar o tipo de condições, como (1) e talvez (2), que estou associando com o florescimento.

162 | Cad. Nietzsche, Guarulhos/Porto Seguro, v.37 n.1, p. 145-184, 2016. 
objetivos medíocres ou sacerdotais. Tais pessoas parecem ser tanto conceitual quanto empiricamente possíveis. Mas a objeção requer que não sejam. Assim, a objeção se confronta com uma dificuldade filosófica imediata. Além do mais, o próprio Nietzsche admite que embora tais tipos possam ser conformados por impulsos conflitantes, eles realizam seus objetivos através da ordenação e domínio de seus impulsos, que são direcionados a objetivos que, quando realizados, expressam os tipos de poder de que são capazes $(J G B / B M 200$, KSA 5.120; GM/GM, III, 15, KSA 5.372). Tipos sacerdotais, por exemplo, são muito eficientes na descoberta, ou criação, das condições que possibilitam a eles satisfazer (1) e (2) mediante o exercício do tipo de poder (sobre si mesmos ou sobre os outros) de que são capazes. A influência que eles têm e à qual Nietzsche se contrapõe se deve justamente a isso. A objeção padece, portanto, de dificuldades tanto filosóficas quanto textuais.

Estas considerações refletem duas dificuldades mais abrangentes para os que pretendem objetar ao modelo de suficiência. Primeiramente, como já havia sido observado, (1) e (2) são condições parcialmente formais. Elas não especificam (como seus dados de entrada) qualquer tipo (particular de) motivos ou objetivos que você deva ter para florescer. Não é claro, portanto, como uma descrição formal como essa poderia fornecer (como dados de saída) o resultado de que apenas aqueles indivíduos com tipos particulares de motivos ou objetivos podem florescer. ${ }^{22}$ A segunda dificuldade é mais restrita à obra de Nietzsche. Muitas descrições do perfeccionismo de Nietzsche desenvolvem uma descrição da agência - do que deve

22 Certamente isso está longe de ser conclusivo: sua descrição formal em busca de adequação extensiva permanece aberta a ajustes. Mas a preocupação é de que as rugas no tapete sempre reaparecem em outro lugar (daí a longa história na filosofia moral de tentativas fracassadas de fornecer resultados substantivos extensivamente perfeitos obtidos a partir de um aparato meramente formal) - e que o único modo de evitar isso é inserir condições substantivas adicionais na descrição formal, de modo que esta se torne em última instância indiscernível de descrições declaradamente substantivas. 
Robertson, R.

ser um agente ideal, ou ao menos um agente qualquer - por meio de condições formais destinadas a evitar que aqueles tipos de pessoas que Nietzsche despreza (por exemplo, tipos sacerdotais) possam contar como agentes ideais (ou mesmo pura e simplesmente como agentes). Muitas dessas descrições produzem resultados desconcertantes. Aqui vai um diagnóstico especulativo de por que isso acontece: elas conjugam dois valores diferentes, florescimento e excelência externa, na suposição de que indivíduos que florescem e indivíduos que alcançam (externamente) coisas excelentes são extensivamente equivalentes. Alguns escritores estabelecem um limite relativamente baixo para o florescimento - geralmente para apresentar uma descrição nietzschiana do florescimento que nós (indivíduos não-excelentes) estivéssemos aptos a satisfazer e que tivesse, portanto, um interesse filosófico mais amplo. ${ }^{23}$ Mas, dada a suposição da equivalência extensiva, tais descrições ficam, assim, comprometidas com a inclusão dos indivíduos não-excelentes entre o tipo ideal de Nietzsche. Ao invés disso, outros estabelecem acertadamente um limite elevado para a excelência nietzschiana ${ }^{\mathbf{2 4}}$ - porém, dada a suposição de equivalência extensiva, estão comprometidos em dizer que apenas indivíduos que alcançam as mais altas excelências realmente florescem. Um bom caminho para se evitar ambas as dificuldades é manter que florescimento e excelência externa são bens distintos.

Deste modo, há uma boa razão interpretativa para considerá-los como distintos. Na medida em que forem assim considerados, podemos aceitar que uma pessoa poderia florescer (ao menos em certo grau, e relativamente ao tipo que ela é) sem, no entanto, se sobressair. Se as coisas se passam desse modo, teria de haver algum argumento adicional e independente para mostrar que (1) e (2) não são suficientes para o florescimento. Mas aqui está uma razão a mais para aceitar o

23 Cf. OWEN, David, op. cit; RIDLEY, Aaron, op. cit; JANAWAY, Christopher, op. cit.

24 Cf. HURKA, Thomas. "Nietzsche: Perfectionist". In. LEITER, B. \& SINHABABU, N. Nietzsche and Morality, ed. Oxford: Clarendon Press, 2007, p. 9-31; REGINSTER, Bernard, op. cit.

164 | Cad. Nietzsche, Guarulhos/Porto Seguro, v.37 n.1, p. 145-184, 2016. 
modelo da suficiência. As duas seguintes generalizações revogáveis são independentemente plausíveis: (a) se você satisfaz (1) e (2), isso é bom para você (ao menos em certo grau); e (b) se você realiza o que é bom para você realizar (satisfazendo (1) e (2)), isso é favorável ao seu florescimento. Entretanto, se (1) e (2) não são suficientes para o florescimento, então seremos obrigados a rejeitar ou (a) ou (b). Mas rejeitar ou (a) ou (b) parece menos plausível do que admitir que (1) e (2) sejam suficientes para o florescimento nietzschiano.

Todavia, é crucial observar que nada do que eu disse até agora elimina a possibilidade de que (por exemplo) tipos sacerdotais floresçam menos que tipos superiores - nem mesmo que eles floresçam menos por causa dos objetivos particulares (perniciosos ou nãoexcelentes de algum outro modo) que realizam. Na verdade, o modelo de suficiência é consistente com a afirmação de que, embora os tipos sacerdotais possam florescer, eles são incapazes de florescer na mesma medida que os tipos superiores - e que essa incapacidade talvez se deva aos tipos de objetivos que eles buscam. (Vou desenvolver essa ideia na próxima seção.) Suficiência é um conceito liminar; e aceitar que (1) e (2) são suficientes para o florescimento nietzschiano implica apenas que alguém que satisfaz estas condições satisfaz certo nível mínimo para o florescimento. ${ }^{25}$ Assim, se você teme que o modelo de suficiência te impeça de dizer que os tipos superiores florescem em um grau mais elevado do que os tipos inferiores, saiba que esse temor é desnecessário.

Para podermos tratar de outras questões, irei daqui em diante supor que (1) e (2) são suficientes para o florescimento nietzschiano (sujeito à condição mencionada no início dessa seção). A próxima seção se dedica a discutir o valor do florescimento. Inicialmente, ela delineia o sentido primário no qual o florescimento é um bem e então

250 que eu disse é igualmente compatível com a ideia de que tipos sacerdotais e medíocres raramente florescem; na verdade, Nietzsche pode estabelecer um nível muito alto para a satisfação de (1) e (2). Meu ponto é apenas de que é pouco convincente insistir na impossibilidade de seu florescimento. 
Robertson, R.

explica como o florescimento de certas pessoas pode ser melhor que o florescimento de outras.

\section{Florescimento: seu valor}

Ao nível individual, o modo primário segundo o qual o florescimento é bom diz respeito ao fato de que ele é bom para a pessoa de cujo florescimento se trata. Entendido deste modo, o florescimento é um bem primordialmente prudencial (seu florescimento é bom para você); e seu valor é primordialmente relacional (é um "bom para..."). ${ }^{26}$ Isso é compatível com a afirmação de que o florescimento é algo valioso como fim: seu florescimento é bom para você, não (ou não apenas) como um meio para algo mais de valor, mas por causa dele (ou de você) mesmo (Cf. Nachlass/FP, 10 [31], KSA 12.471; 10 [11], KSA 12.459). ${ }^{27} \mathrm{O}$ florescimento poderia ser bom também em outros sentidos. Aqui, no entanto, eu foco em seu ser bom para a pessoa de cujo florescimento se trata.

Isso pode ser lido como uma afirmação de que a propriedade de florescer é um bem para a pessoa que a possui. Porém, no que diz respeito apenas à conexão lógica entre florescimento e valor, a ideia central é essa: se A floresce, isso é bom para $A .^{28} \mathrm{Na}$ leitura

26 Para reivindicações semelhantes (veja LEITER, B. Nietzsche on Morality, p. 106). Todavia, a descrição que esbocei no $§ 2$ se distancia de Leiter de várias maneiras, inclusive por não pressupor que existem "fatos referentes aos tipos que sejam imutáveis" nos agentes.

27 Estou assumindo que há uma diferença entre dois tipos de contraste de valor: um contraste de valor final/instrumental e um contraste de valor intrínseco/relacional (veja KORSGAARD, Christine: ‘Two Distinctions in Goodness'. In. Philosophical Review 92, 1983, p.169-95). Assim, não estou atribuindo a Nietzsche a afirmação, a que muitos objetam corretamente sobre bases textuais, de que certas coisas são intrinsecamente valorosas em algum sentido metafisicamente mais carregado. Para dificuldades resultantes do modo como certos comentadores fundem a distinção final-intrínseca, veja "Nietzsche’s Ethical Revaluation", p. 83-84; THOMAS, Alan. "Nietzsche and Moral Fictionalism". In. JANAWAY, C. \& ROBERTSON, S. Nietzsche, Naturalism and Normativity. Oxford: Oxford University Press, 2012, p. 139.

28 (a) Poderia ser bom, claro, em algum sentido adicional que certas pessoas não floresçam (ou não floresçam do modo como fazem); mas isso é consistente com a tese de que o florescimento

$166 \mid$ Cad. Nietzsche, Guarulhos/Porto Seguro, v.37 n.1, p. 145-184, 2016. 
nietzschiana substantiva do florescimento, segundo a qual (1) e (2) são suficientes para o florescimento humano, isso implica que: se $A$ alcança um grau relevante de unidade psicológica e expressa quem ele é por meio da realização dos objetivos adequadamente estabelecidos para si mesmo, isso é bom para $A .^{29}$

Assim como no caso do florescimento, o valor do florescimento ocorre em graus. Considerando a vida inteira de uma pessoa singular, quanto mais essa pessoa floresce, melhor é sua vida como um todo (enquanto florescimento) - desde que sujeito às ressalvas habituais em relação ao formato de sua vida, inclusive a de que uma vida melhor tem mais propensão a apresentar uma trajetória ascendente de florescimento do que uma degeneração declinante. ${ }^{30}$ Digamos que, em relação (apenas) ao florescimento do qual A é capaz (e assim pondo entre parênteses todo o resto, isto é, tudo exceto o florescimento de A), se A floresce no grau máximo do qual é capaz, A vive uma vida que é maximamente boa (ou melhor) para A. E, relativizado da mesma maneira, o grau em que A floresce é correlativo ao grau em que a vida que A vive é boa para A. Assim, neste sentido restrito, quanto maior o grau em que A floresce, melhor é a vida de A para si

de uma pessoa é bom para aquela pessoa. (b) O "bom" é aqui pro tanto. Você poderia florescer de um modo que é bom para você em algum grau mesmo se (digamos) as condições sociais severas nas quais você se encontra são tais que, se você florescer em um alto grau agora estará solapando as condições para que floresça mais tarde na vida. De modo geral, algumas vezes pode ser prudente, dadas as condições nas quais você se encontra, não maximizar seu potencial e assim não florescer maximamente em relação a esse potencial. Sendo assim, considerações prudenciais além daquelas que têm a ver com o florescimento poderiam fazer com que fosse melhor para você não florescer (mesmo que o florescimento ainda seja bom pro tanto). Poderia haver, por sua vez, conflitos entre diferentes vertentes da prudência.

29 Estou desconsiderando aqui a questão se satisfazer apenas (1) ou apenas (2) poderia ser bom para você. Há muitas rotas possíveis que poderiam ser assumidas aqui, embora estas questões não afetem a presente descrição.

30 Veja, por exemplo, MCMAHAN, Jeff. "Death and the Value of Life”. In. Ethics 99/1, 1988, p. 32-61; VELLEMAN, David. The Possibility of Practical Reason. Oxford: Oxford University Press, 2000, especialmente: "Well-Being and Time" p. 56-84. Tenham em mente as observações do próprio Nietzsche em relação a morrer na hora certa, quando não estamos mais em ascensão (por exemplo, GD/CI, Incursões de um extemporâneo 36, KSA 6.134).

Cad. Nietzsche, Guarulhos/Porto Seguro, v.37 n.1, p. 145-184, 2016. | 167 
Robertson, R.

mesma. Isso permite comparações entre o valor do florescimento de acordo com a vida efetiva de uma pessoa e as trajetórias alternativas da vida dessa pessoa. E isso é importante se queremos permitir que, ao florescer mais, você pode viver uma vida que é melhor para você do que uma vida na qual você floresce menos.

Podemos expandir esse modelo básico de modo que ele permita também algumas comparações interpessoais. ${ }^{31}$ Considere, primeiramente, o seguinte caso simplificado de dois agentes. Suponha que A maximiza seu potencial e nesse sentido floresce maximamente em relação ao grau de florescimento de que é capaz, enquanto B floresce significativamente abaixo do grau de que é capaz. Em relação apenas ao florescimento do qual A e B são capazes (portanto, permanecendo tudo mais o mesmo), podemos dizer que a vida que $A$ vive é melhor para $A$ do que a vida que $B$ vive é para $B$.

Agora considere um segundo caso no qual tudo mais não é o mesmo. Ambos, A e C, florescem igualmente (vamos supor, maximamente) em relação ao grau de florescimento de que são capazes (cada qual realiza seu potencial inteiramente). Mas A produz arte excelente do tipo que Nietzsche enaltece, enquanto $\mathrm{C}$ realiza objetivos que Nietzsche considera ou totalmente inexpressivos (mundanos ou medíocres, digamos) ou com valor decididamente negativo (perniciosamente sacerdotais, digamos). Nietzsche poderia dizer que a vida de A é melhor, mais valorosa em aspectos importantes. Mas ele julgaria que A e $\mathrm{C}$ florescem igualmente, de modo que a vida que $\mathrm{C}$ vive é tão boa para $C$ quanto a vida que $\mathrm{A}$ vive é boa para $A$ ? Há duas posições principais que podem ser assumidas em relação a essa questão. Conforme a primeira posição, que poderíamos chamar de modelo "estreito", o grau de valor que o florescimento

31 Algumas leituras de Nietzsche descartam implicitamente modos plausíveis de fazer tais comparações interpessoais (por exemplo, LEITER, B. "Nietzsche's Metaethics: Against the privilege Readings"; ROBERTSON, Simon, "Nietzsche’s Ethical Revaluation”, p. 82-83). Muitas descrições não conseguem explicar adequadamente os graus de valor de forma integral; a descrição oferecida na sequência pretende cobrir essa lacuna.

$168 \mid$ Cad. Nietzsche, Guarulhos/Porto Seguro, v.37 n.1, p. 145-184, 2016. 
de uma pessoa tem para essa pessoa é determinado exclusivamente pelo grau no qual a pessoa satisfaz as condições (1) e (2). Nesse modelo, já que A e $\mathrm{C}$ florescem igualmente, $\mathrm{C}$ vive uma vida que é tão boa para $\mathrm{C}$ quanto a vida que $\mathrm{A}$ vive é boa para $\mathrm{A}$, ainda que $\mathrm{A}$ se sobressaia e C não. Para uma segunda posição, embora satisfazer (1) e (2) seja suficiente para florescer em certo grau, o grau de valor que o florescimento de uma pessoa tem para esta pessoa pode ser determinado por fatores outros que a satisfação de (1) e (2). Tais fatores podem incluir o valor dos objetivos que a pessoa realiza. Chame isso de modelo "amplo". Nesse modelo, a vida de A poderia ser melhor para $\mathrm{A}$ que a vida de $\mathrm{C}$ é para $\mathrm{C}$, precisamente porque A se sobressai e C não.

Assim, Nietzsche endossaria (ou deveria endossar) o modelo estreito ou o amplo? O modelo estreito implica, na medida em que um tipo sacerdotal, medíocre e superior realiza cada qual seu potencial no mesmo grau, (i) que a vida que um tipo sacerdotal ou medíocre vive poderia ser tão boa para ele quanto a vida que um tipo superior vive é boa para ele, e (ii) que um tipo sacerdotal ou medíocre poderia florescer no mesmo grau que um tipo superior. O modelo amplo nos permite negar tanto (i) quanto (ii). Suspeito que Nietzsche optaria pelo modelo amplo. A opção por esse modelo confere sentido ao fato de que ainda que pessoas não-excelentes possam florescer, a espécie de florescimento que os tipos superiores realizam é significativamente melhor que a espécie de florescimento que os não-excelentes (por exemplo, tipos de rebanho e sacerdotais) realizam - e melhor não apenas no sentido de que tipos superiores vivem vidas melhores (por exemplo, mais impressionantes ou admiráveis), mas de que a vida que o tipo superior vive é melhor para ele do que a vida que um tipo sacerdotal ou medíocre vive é para ele. Em suma, o modelo amplo permite que você floresça em grau maior e viva uma vida que é melhor para você se você buscar e realizar objetivos que valem mais a pena (ou, para Nietzsche, que são genuinamente excelentes). 
Robertson, R.

Isso é independentemente plausível. ${ }^{32} \mathrm{O}$ modelo estreito não permite isso, e esta é uma razão para preferir o modelo amplo.

Eis uma segunda razão para preferi-lo. Suponha que C floresce maximamente em relação ao seu potencial, mas realiza fins que carecem de valor ou são medíocres, enquanto D se sobressai pela realização de certos objetivos genuinamente excelentes, embora floresça consideravelmente menos do que poderia em relação ao seu potencial. Agora considere a questão "quem floresce mais e assim vive uma vida melhor: C ou D?". Suspeito que muitos nietzschianos responderiam " $\mathrm{D}$ "; mas eu também suspeito que, de todo modo, muitos de nós não estaríamos seguros disso. Note, no entanto, que o modelo estreito implica que $\mathrm{C}$ vive uma vida que é melhor para ele do que a vida que $\mathrm{D}$ vive é para ele. $\mathrm{O}$ modelo amplo, por sua vez, permite (embora não exija) o veredito contrário. Ele acomoda o veredito " $\mathrm{D}$ vive uma vida melhor" porque admite que a vida de D poderia ser melhor em virtude de D realizar um número maior de objetivos que valem a pena. (No entanto, ele não exige esse veredito, porque, ao contrário do modelo estreito, ele permite que o grau de valor que a vida de uma pessoa tem para essa pessoa dependa de algo mais do que apenas o grau no qual satisfaz (1) e (2) - ele pode depender também, por exemplo, de quão valoroso é realizar excelências.) Além do mais, isso agora ajuda a explicar por que você poderia estar sem saber se a vida de C é melhor para C do que a vida de $\mathrm{D}$ é para $\mathrm{D}$ (ou vice versa). A explicação é de que há dois valores diferentes em

32 Para um modelo de valor estruturalmente similar, veja, por exemplo, PARFIT, Derek. Reasons and Persons. Oxford: Oxford University Press, 1984, p. 501-502. Eis aqui uma argumentação aparentada a favor do modelo amplo: imagine que a pessoa A tem o potencial de realizar objetivos altamente valorosos (grande arte, por exemplo). Em uma trajetória, A realiza aquele potencial. Em outra trajetória, no entanto, A sofre um terrível acidente, deixando seu potencial consideravelmente diminuído (embora, vamos imaginar, ela não esteja atenta a isso). Nessa segunda trajetória, a pessoa, chamemos ela de $\mathrm{A}^{*}$, é capaz de realizar apenas objetivos banais. Entretanto, mesmo se A e A* realizam seus potenciais no grau máximo de que cada um é capaz, normalmente preferiríamos viver a vida de A e pensaríamos que A vive uma vida mais florescente que A*. Isso dá suporte ao modelo amplo.

$170 \mid$ Cad. Nietzsche, Guarulhos/Porto Seguro, v.37 n.1, p. 145-184, 2016. 
jogo: florescimento $e$ excelência. $\mathrm{E}$ a presença desses dois valores concorrentes torna difícil emitir um único veredito conclusivo, pois não sabemos ainda como se funde o valor desses dois valores. Assim, a menos que você tenha as intuições resolutas de que $\mathrm{C}$ vive uma vida mais florescente que $\mathrm{D}$ e que a vida de $\mathrm{C}$ é melhor para $\mathrm{C}$ do que a vida de $\mathrm{D}$ é para $\mathrm{D}$, você deveria achar o modelo amplo mais atrativo. (Isso também traz mais água para o meu moinho: devemos manter o florescimento como algo distinto da excelência; caso contrário, é difícil saber como poderíamos, mesmo em princípio, chegar a emitir juízos sobre C ou D).

Esta discussão poderia ser muito mais detalhada; mas o que foi dito é suficiente para expor a visão básica do florescimento e seu valor. Até aqui, portanto, eu delineei uma explicação substantiva do florescimento nietzschiano por meio de dois conjuntos principais de condições e ofereci um modelo para entender como o florescimento pode ser bom para uma pessoa. Ao longo do trajeto, eu também expliquei como podemos comparar o valor do florescimento em diferentes pessoas; e ofereci algumas razões do porquê de precisarmos distinguir o florescimento das excelências externas, se queremos conferir sentido às posições avaliativas de Nietzsche. Passamos agora às excelências externas.

\section{Excelências externas}

Eu sugeri que o florescimento é algo que poderia, em princípio, ser alcançado por pessoas que não se enquadram nos tipos superiores nietzschianos. $\mathrm{O}$ que distingue os tipos superiores do resto, entretanto, é que eles também se sobressaem através da realização de fins genuinamente excelentes. Dois apontamentos iniciais.

Primeiro, "excelência" é ela mesma um termo avaliativo. Ele denota algo que não é meramente bom, mas altamente ou excepcionalmente bom - grande, impressionante, admirável, digamos. 
Robertson, R.

A "Excelência", tal como venho usando o termo, não está confinada aos usos atributivos (como um modulador predicativo) no sentido de que, se $x$ é (atributivamente) bom, então ele é um bom $x$. Poderia ser verdade que Paul fosse um bom cristão e Jack, o estripador, um excelente assassino em série - nisso, relativamente a qualquer coisa que seja requerida para ter êxito nesses papeis, Paul e Jack se saíram muito bem. Mas daí não se segue (e em termos substantivos, Nietzsche, sem dúvida, negaria) que as coisas que Paul e Jack fizeram para se sobressair enquanto cristão ou enquanto assassino em série foram boas (muito menos excelentes) em algum sentido adicional (não atributivo). Da Vinci, por outro lado, foi não apenas um excelente exemplo de artista, mas (na visão que estou sugerindo) manifestou a excelência em certo sentido adicional (não atributivo). O que os distingue é o valor dos objetivos que buscaram e realizaram: Paul e Jack realizaram fins destituídos de valor (embora, muito eficientemente), enquanto da Vinci produziu algo excepcionalmente valoroso, isto é, excelente. Irei tratar, portanto, a "excelência" como um predicado avaliativo (não um predicado modulador) para denotar coisas que são boas em algum sentido não capturado por usos meramente atributivos.

Segundo, vale perguntar se Nietzsche considera conquistas, ou pessoas que as alcançam, como excelentes. Por um lado, é central na sua visão de perfeccionismo um tipo ideal de pessoa a quem ele atribui vários epítetos: "espírito livre" (FW/GC 347, KSA 3.581; JGB/ $B M$, Cap. 2, KSA 5.41-60), "tipo superior" (JGB/BM 62, 228, KSA 5.81,163; $A C / A C$ 4, KSA 6.171; EH/EH, Por que sou um destino, 4, KSA 6.367), "nobre" (FW/GC 55, KSA 3.417; JGB/BM 287, KSA 5.232), "grande" (Nachlass/FP 37 [8], KSA 11.580), possivelmente também “Übermensch" (Za/ZA Prólogo, 3 KSA 4.14; EH/EH, Por que escrevo livros tão bons 1, Por que sou um destino 5, KSA 6.298, 369). Como prováveis exemplares, ele fornece uma gama de indivíduos à primeira vista bastante diversos, que inclui César, da Vinci, Goethe, Beethoven. Além disso, ele cita repetidamente uma seleção de 
capacidades ou qualidades de caráter (frequentemente em associação com tais exemplares) que poderiam ser entendidas de variadas formas como precondições para, e em alguns casos como parcialmente constitutivas do que é ser um indivíduo excelente - notadamente, certas qualidades "auto-orientadas" (algumas das quais são também necessárias para o florescimento): o autodomínio (M/A 109, KSA 3.96; JGB/BM 200, 260, KSA 5.120, 208; GD/CI, Incursões de um extemporâneo 49, KSA 6.151; Nachlass/FP 14 [219], KSA 13.394), a autodisciplina necessária para enfrentar o sofrimento e superar as resistências (internas e externas) (JGBBM 212, 225, 260, 270, KSA $5.145,160,208,225)$, uma vontade independente e autodeterminada, necessária para estabelecer e realizar seus próprios objetivos (JGB/ $B M$ 29, 60, KSA 5.47, 79; $F W / G C$ 290, 347, KSA 3.530, 581), autossuficiência $(F W / G C$ 55, KSA 3.417; JGB/BM 44, 212, 260, 274, 284, KSA 5.60, 145, 208, 227, 231) e autorreverência $(F W / G C 287$, 290, KSA 3.528, 530). Muito da ênfase de Nietzsche recai sobre o que deve ser uma pessoa excelente; e ele frequentemente parece enaltecer certas pessoas não tanto em função de suas conquistas particulares, mas por elas manifestarem uma variedade de qualidades auto-orientadas. De todo modo, uma pessoa pode possuir e exercer tais qualidades e, no entanto, dirigir suas atividades a objetivos aos quais nós (ou Nietzsche) negaríamos qualquer excelência visível. À luz disso, embora Nietzsche frequentemente atribua excelência às pessoas, uma pessoa manifesta excelência apenas na medida em que ela realiza coisas excelentes.

Esse ponto suscita uma grande questão: o que conta como uma realização excelente na visão de Nietzsche e por quê? Seus próprios exemplos se concentram geralmente na grande arte, na música, na ciência e na filosofia (talvez também em certos feitos políticos), embora isso talvez pudesse ser estendido a fim de incluir outras realizações que envolvem a superação de desafios significativos, os quais exigem níveis excepcionalmente elevados de autodomínio e 
Robertson, R.

agência efetiva. Mais importante que isso, no entanto, é o fato de Nietzsche dizer pouco, notoriamente, tanto acerca de quais objetivos (se realizados) representariam realizações excelentes quanto acerca de como distinguir precisamente estas realizações de realizações que ficam aquém da mais elevada excelência. Isso pode parecer uma flagrante omissão. Todavia, pode haver uma boa explicação para isso: a excelência, Nietzsche defende, é incodificável. ${ }^{33} \mathrm{O}$ restante desta seção explica por que as coisas se dão desse modo.

$\mathrm{Um}$ primeiro ponto diz respeito à unidade psicológica que propus anteriormente como um ingrediente necessário ao florescimento nietzschiano. Tipos superiores são caracterizados por impulsos especialmente fortes, mas também diversos, os quais são redirecionados de modo unificado (JGB/BM 200, KSA 5.120; GD/ CI, Incursões de um extemporâneo 49, KSA 6.151). É plausível que uma tal pessoa tenha mais probabilidade de produzir algo significativamente novo: quanto maior a diversidade de motivos de que se parte, maior a probabilidade de se acabar diferente da norma - maior a probabilidade de fazer de si mesmos algo novo e assim se "tornar [quem eles] são [...] seres humanos que são novos, únicos, incomparáveis [...] que criam a si mesmos" (FW/GC 335, KSA 3.560). ${ }^{34}$ No entanto, como uma pessoa faz de si algo novo por meio da ordenação de seus motivos diversos é algo para o qual não podemos oferecer um modelo codificável.

33 Uma explicação diferente, apregoada, por exemplo, por HURKA, Thomas, op. cit. e JANAWAY, C., op. cit, é de que Nietzsche oferece uma descrição formal da excelência. Para dificuldades relativas à questão se uma descrição exclusivamente formal pode fazer todo o trabalho necessário para distinguir excelência de não-excelência, veja REGINSTER, B., op. cit., ROBERTSON, S., op. cit (no prelo, Cap. 9), assim como o $\$ 3$ do presente artigo.

34 Compare com alguém que internaliza as normas e demandas de alguma autoridade externa, por exemplo, sócio-moral. Isto provavelmente o leva a suprimir ou extirpar motivos que são antitéticos à norma, o que por sua vez sufoca qualquer capacidade de independência de pensamento e ação que ele possa ter tido. $\mathrm{O}$ resultado é alguém que não apenas se conforma de forma dócil às normas preestabelecidas, mas que se torna muito parecido aos outros do rebanho (Cf. GM/GM, I, 14, II, 1 III, 1, KSA 5.281, 291, 339; JGB/BM 199, KSA 5.119; FW/GC 290, 374, KSA 3.530, 626).

$174 \mid$ Cad. Nietzsche, Guarulhos/Porto Seguro, v.37 n.1, p. 145-184, 2016. 
Segundo, tipos superiores de espírito livre são agentes autodeterminados que estabelecem seus próprios objetivos. Nietzsche enfatiza constantemente que um espírito livre é marcado por uma considerável independência de pensamento e ação: ele é "a exceção" que "pensa ao contrário do que se esperaria", que se mantém à parte da maioria arrebanhada (MA I/HH I 225, KSA 2.189; FW/ GC 55, KSA 3.417; JGB/BM 44, 212, 260, 274, 284, KSA 5.60, $145,208,227,231)$ e que, ao invés de se submeter a autoridades preestabelecidas, impostas externamente, possuem uma vontade independente, autodeterminada, cujo exercício envolve estabelecer seus próprios fins $(F W / G C 290,301,335,347, \mathrm{KSA} 3.530,539,560$, 581; $Z a / Z A$, Dos mil e um alvos, KSA 4.74; JGB/BM 29, 60, 260, KSA 5.47, 79, 208; AC/AC 11, KSA 6.177). Um espírito livre é um experimentador e inovador (MA I/ HH I, Prólogo, 4, KSA 2.17; M/A 453, 501, KSA 3.274, 294; JGB/BM 42, 205, 210, KSA 5.59, 132 , 142; GM/GM, II, 24, KSA 5.335 Nachlass/FP 37 [8], KSA 11.580), alguém que, por meio da atividade criativa, realiza novos fins de forma inovadora (MA I/HH I, 231, KSA 2.194; FW/GC 301, 335, KSA 3.539, 560; JGB/BM 260, KSA 5.208). De fato, um espírito livre "se sente como quem determina os valores... ele cria valores" (JGB/BM 260, KSA 5.208; $F W / G C$ 301, 335, KSA 3.539, 560; $Z a / Z A$, Dos mil e um alvos, KSA 4.74). Não fica totalmente claro o que é "criar valores". Mas uma coisa que Nietzsche deve querer dizer com isso é que um tipo superior de espírito livre cria ou estabelece seus próprios fins e que a realização desses fins é (enquanto realização da excelência) valorosa. Novamente, entretanto, quais objetivos um espírito livre autodeterminado, independente, inovador e experimentador cria para si mesmo não é o tipo de coisa que se pode especificar por meio de uma fórmula genérica.

Terceiro, a excelência mesma, por sua própria natureza, impossibilita uma receita codificável. Na visão de Nietzsche, isso envolve fazer algo extraordinário, novo, sobrepujar os idiomas 
Robertson, R.

convencionais e assim por diante, resultando de uma atividade imensamente criativa - os "homens realmente grandes", escreve Nietzsche, são "homens de grande criatividade" (Nachlass/FP 37 [8], KSA 11.580; cf. $F W / G C$ 290, 301, 335, KSA 3.530, 539, 560). No entanto, a criatividade, por sua própria natureza, não é algo para o qual podemos oferecer uma receita determinada, explicando como alcançá-la. ${ }^{35}$

A primeira conclusão geral a ser extraída diz respeito ao porquê de Nietzsche não oferecer, em nenhum lugar, uma fórmula para a excelência - uma descrição especificando, com algum conteúdo determinado, com que se pareceriam as realizações excelentes enquanto-ainda-não-realizadas: a excelência é alcançada por indivíduos que unificam um arranjo de motivos de modo único e cujas ações são subsequentemente criativas, transcendendo as regras. Isso não quer dizer que, uma vez alcançada, não podemos reconhecer a excelência. Isso, na verdade, explica por que não podemos especificar de antemão em que consiste exatamente a excelência ou, por conseguinte, como alcançá-la.

Uma segunda conclusão importante diz respeito à relação entre florescimento e excelência. Alcançar a excelência requer geralmente a satisfação das condições para florescer (representadas pelas condições (1) e (2) do §2). Além disso: já que os motivos de um tipo superior, que ele precisa expressar através da ação a fim de expressar quem ele é, são direcionados a objetivos que (se realizados) exemplificam a excelência, é por meio da realização de excelências relevantes que ele floresce. Essa explicação, portanto, mostra como o florescimento e a excelência, embora distintos, estão conectados. Eles são distintos na medida em que alguém pode florescer sem se sobressair. Entretanto, alguém que se sobressai de modo geral floresce justamente por isso. ${ }^{36}$ Além do mais, visto que os tipos superiores

35 Para uma defesa e análise estendida dessa ideia, veja RIDLEY, Aaron, op. cit.

36 Digo "de modo geral” porque há ao menos espaço conceitual para imaginar alguém que se

$176 \mid$ Cad. Nietzsche, Guarulhos/Porto Seguro, v.37 n.1, p. 145-184, 2016. 
são caracterizados por impulsos fortes que precisam de expressão, e visto que eles se expressam através da realização de objetivos que consideram não apenas significativos, mas genuinamente valorosos enquanto realização de grandes excelências, é provável que (dado o modelo amplo defendido em $\S \S 3-4$ ) eles floresçam em um alto grau.

\section{O valor da excelência}

Florescer é bom para a pessoa que floresce, mas não precisa ser bom em qualquer outro sentido. A excelência também é de modo geral algo bom para a pessoa que a realiza, já que alguém que realiza a excelência de modo geral floresce. No entanto, a excelência é também valorosa em outro sentido. Essa secção esclarece brevemente qual tipo de valor devemos atribuir à excelência.

Por um lado, o núcleo avaliativo da excelência é, ao invés de prudencial, primariamente não-prudencial. As composições musicais de Beethoven, suponhamos, são exemplos de realização humana altamente excelente. Mas o valor que têm enquanto excelência não é primariamente uma questão de serem boas para Beethoven (por

sobressaia, mas que não floresça. Vale considerar alguns casos diferentes aqui, a fim de ver quão típica é a conexão. Imagine, primeiramente, um gênio torturado: alguém que se sobressai, mas que vive o que parece uma vida bastante infeliz (um Frege, Wittgenstein, Turin ou mesmo Nietzsche, talvez). De todo modo, isso não é problemático para o modelo que desenvolvi. $\mathrm{Na}$ medida em que essas pessoas expressam algo importante sobre quem elas são através das excelências que alcançam, elas florescem ao menos em certo grau relativo aos tipos de pessoas que são. (O florescimento deveria, portanto, ser distinguido das descrições puramente empíricas, por exemplo hedonistas, de uma vida boa: uma vida florescente não precisa ser uma vida de prazer em um sentido hedonista padrão - com o que Nietzsche certamente concorda; veja, por exemplo, GM/GM III 14, KSA 5.367; GD/CI, Máximas e flechas 12, KSA 6.60). Em segundo lugar, poderíamos imaginar alguém que conquista algo excelente, mas com isso não expressa quem ele é de maneiras necessárias para florescer, talvez porque ele seja avesso à atividade na qual se sobressai. Há margem de manobra aqui: poderíamos sugerir que ele expressa algo importante sobre si mesmo e que essa é a razão pela qual ele gasta o tempo que gasta produzindo a excelência que ele produz - ele assim floresce ao menos em algum grau. De todo modo, se há casos extremos onde mesmo isso é falso, podemos apenas admitir que se sobressair implica ou pressupõe de modo geral, mas não acarreta rigorosamente o florescimento.

Cad. Nietzsche, Guarulhos/Porto Seguro, v.37 n.1, p. 145-184, 2016. | 177 
Robertson, R.

exemplo, torná-lo capaz de florescer); nem tampouco seu valor é primariamente uma questão de serem boas para nós (por exemplo, por meio do prazer que nos dá ou por facilitar nosso florescimento). Por outro lado, o valor da excelência não é primariamente relacional, ao menos não no sentido de que o tipo de valor que as composições mais refinadas de Beethoven manifestam é bem entendido em termos do seu ser bom para. Seu valor tem antes algo a ver com o simplesmente ser excelente. Um modo de apreender isso é dizer que a excelência é valorosa como fim - admirável ou impressionante, digamos, isto é, digna de admiração, por si mesma, e não como um meio para (ou por) outro algo valoroso. Realizações excelentes específicas são da mesma maneira admiráveis, impressionantes etc., por direito próprio ou por si mesmas - grandes simplesmente como expressões do mais alto potencial da humanidade. Não penso que haja muito mais que possa ser dito, ou que precise ser dito, sobre o tipo de valor constituído pela excelência.

Entretanto, chamar algo de "excelente" também implica que seja excepcionalmente bom. Nietzsche sugere algumas vezes, além disso, que realizar as mais elevadas excelências é mais valoroso que qualquer outra coisa (ou aquelas pessoas que as realizam são melhores que as outras). Isso levanta numerosas questões sobre como o valor da excelência se compara a outros bens: se, por exemplo, uma instância da excelência é mais valorosa que qualquer número de instâncias de outros bens, se isso é porque a excelência é incomensuravelmente mais valorosa que os outros bens, se seu valor se encontra em uma escala avaliativa diferente, descontínua com os outros bens, e assim por diante. Embora Nietzsche não tenha abordado essas questões explicitamente, pode-se esperar que ele assuma uma posição perfeccionista forte, segundo a qual a excelência é descontinuamente superior ao mero florescimento de muitos. ${ }^{37}$

37 Passagens relevantes incluem WB/Co. Ext. IV 6, KSA 1.462; JGB/BM 258, KSA 5.202; GM/GM, I, 17, KSA 5.288; Nachlass/FP 5 [108], KSA 12.228. Em Robertson (no prelo, Cap.

178 | Cad. Nietzsche, Guarulhos/Porto Seguro, v.37 n.1, p. 145-184, 2016. 
Todavia, há numerosas vias possíveis para explorar essas questões. ${ }^{38}$ E não precisamos seguir Nietzsche. Na verdade, poderíamos rejeitar esse aspecto do seu perfeccionismo enquanto mantemos tudo o mais até aqui delineado na explicação do florescimento e da excelência. Para concluir, irei reunir as ideias anteriores e explicar por que o modelo geral delas resultante pode ser atrativo.

\section{Considerações finais}

As considerações apresentadas constituem, com efeito, um modelo perfeccionista de uma boa vida. São centrais nesse modelo dois bens fundamentais: o florescimento e a excelência. $\mathrm{O}$ núcleo avaliativo do florescimento é relacional e prudencial: florescer é bom para a pessoa de cujo florescimento se trata. O núcleo avaliativo da excelência, ao contrário, é não-relacional e não-prudencial: uma realização que incorpore a excelência é, simplesmente, excelente - excepcionalmente boa por direito próprio, como expressão do potencial humano mais elevado. Espero que a descrição seja atrativa em diversos níveis.

Em nível interpretativo, primeiramente, ela nos possibilita combinar elementos que Nietzsche herda de duas tradições perfeccionistas distintas. Os comentadores nem sempre distinguem claramente florescimento e excelência, e muito menos explicam como eles se conectam. Isso frequentemente gera dificuldades interpretativas e filosóficas. A descrição oferecida fornece um modo de evitar estes problemas. Além disso, ao longo do texto, sintetizei e reconciliei numerosos pontos potencialmente conflitantes da

9), argumento que isso não implica, e Nietzsche não busca promover a excelência de alguns poucos por meio de algum conjunto de arranjos políticos fortemente anti-igualitário (comparar, por exemplo, com HURKA, Thomas, op. cit).

38 Veja a vasta literatura dedicada a Mill sobre os prazeres superiores e inferiores - o que levanta questões muito vastas para serem abordadas aqui. 
Robertson, R.

concepção nietzschiana de florescimento, expliquei como este está conectado à excelência e ofereci um modo de estimar os graus de valor (incluindo comparações interpessoais).

Em nível estrutural, em segundo lugar, a descrição combina tanto bens prudenciais quanto não-prudenciais. Mesmo aqueles que são pouco simpáticos aos aspectos substantivos do próprio perfeccionismo de Nietzsche - a reivindicação exigente e romantizada da excelência criativa, por exemplo, ou a supremacia avaliativa da excelência sobre o bem dos indivíduos - poderiam aceitar sua estrutura subjacente. Na verdade, poder-se-ia substituir o bem nietzschiano da excelência por uma descrição substantivamente diferente dos valores não-prudenciais (mesmo valores morais poderiam contar como candidatos aqui).

Todavia, em terceiro lugar, eu espero ainda que o modelo de vida boa ou de vida florescente seja plausível também do ponto de vista substantivo. Em termos mais gerais, florescimento requer eficácia psicológica e agência efetiva, além do entrosamento adequado entre eles. Daí emerge um conjunto mais amplo de características gerais: autocompreensão, integração psicológica, autonomia, a expressão de si através das ações, a realização de objetivos que você considere significativos. Pode-se supor de forma plausível e independente [dos demais compromissos teóricos do modelo] que estes bens sejam necessários para que a vida de uma pessoa vá bem e que contribuam para que se viva uma vida minimamente boa ou completa. Além disso, a descrição também permitiu (mas não impôs) que se abrisse espaço para a ideia segundo a qual alguém pode florescer mais completamente se ele realizar, de forma independente, objetivos mais valorosos. Para Nietzsche, tais objetivos são aqueles que incorporam as mais elevadas excelências. De todo modo, quer sigamos Nietzsche nisso quer não, a ideia subjacente continua plausível: frequentemente pensamos que alguém floresce mais completamente e vive uma vida melhor na medida em que realiza mais fins valiosos. 
Note que, em um nível axiológico, a descrição compartilha certas afinidades com o que é algumas vezes chamado de um modelo de "lista objetiva" ou de "bem substantivo"39. Para usar uma terminologia que evitei até o momento, o modelo é compatível com a ideia de que, para Nietzsche, o florescimento e a excelência são ou poderiam ser objetivamente valiosos, ao menos no seguinte sentido mínimo: o fato de serem valiosos (seu florescimento ser bom para você, por exemplo, ou a sinfonia pastoral de Beethoven ser uma realização excelente) não depende somente de alguma pessoa particular acreditar que eles sejam bons ou os aprovem. As condições substantivas para o florescimento identificadas - autocompreensão, integração psicológica, autonomia, agência efetiva e autoexpressiva, realização de objetivos que você considera significativos etc. - poderiam da mesma forma indicar bens "objetivos": se a realização desses bens contribui para que você viva um vida florescente de modos que são bons para você não depende somente de você acreditar que eles são bons ou de aprová-los. Se cada um desses bens pode ser incluído em tal "lista" é uma questão substantiva aberta ao diálogo substantivo; eu tentei mostrar como é plausível incluí-los em tal lista. Uma objeção comum aos modelos de lista objetiva é que eles são insuficientemente sensíveis às particularidades dos indivíduos para os quais estes itens da lista são bons. Uma virtude da descrição nietzschiana é a de não manter esta objeção de pé. Relembre que os bens gerais

39 (Cf. SCANLON, T.M. What we owe to each other. Cambridge, Massachusetts: Belknap Press of Harvard University Press, 1998, cap. 2 e 3; PARFIT, Derek, op. cit., p. 501-502). (a) Mais precisamente, sua estrutura geral é um pouco como o modelo de satisfação de desejos e a lista objetiva híbrida de Parfit: sua vida geralmente seguirá melhor se há um alinhamento apropriado entre o que você deseja e o que é “objetivamente bom”. No entanto, há diferenças importantes, incluindo que na descrição nietzschiana do que é objetivamente bom para uma pessoa é parcialmente constituído por condições subjetivas (motivos, habilidades etc.) que fazem dessa pessoa a pessoa particular que ela é - veja abaixo. (b) Modelos de lista objetiva são tipicamente considerados como a principal alternativa para explicações do valor hedonistas (ou, de modo mais geral, empiristas) e explicações baseadas na satisfação de desejos. Em Robertson (no prelo, Cap. 10) explico de modo mais completo como esse modelo nietzschiano não se reduz a nenhuma dessas alternativas e de que maneira, como um resultado, ele evita dificuldades comuns a eles. 
Robertson, R.

listados podem ser realizados de muitos modos diferentes; e o modo como devem ou podem ser realizados de maneiras que contribuam para que uma pessoa particular viva uma vida boa ou florescente, dependerá de uma série de condições subjetivas relacionadas àquela pessoa - incluindo, decisivamente, seus motivos, mas também sua configuração psicológica em geral, suas habilidades e o contexto social no qual ela se encontra. Dadas essas variáveis, algo que é bom para uma pessoa pode não ser bom para outra. Nesse sentido, embora possamos especificar em termos gerais uma série de características que integram uma vida boa ou florescente, os modos nos quais é bom ou apropriado para um indivíduo realizar estes bens gerais depende da natureza e da situação desse indivíduo (algo para o qual, assim como para a excelência nietzschiana, não há receita universal). Portanto, o caráter "objetivo" dos bens gerais listados é moderado pelas condições subjetivas e contextuais que constrangem e moldam como os bens são adequadamente realizados por diferentes indivíduos. $\mathrm{O}$ caráter objetivo dos bens gerais impede que a descrição apresentada sucumba a uma forma tosca de subjetivismo; ao mesmo tempo em que as condições subjetivas garantem que a descrição seja adequadamente sensível aos indivíduos para os quais aqueles bens são bons.

Muito mais coisas poderiam ser ditas, tanto para fundamentar essa descrição do valor nietzschiano quanto para defendê-la de possíveis objeções. Por ora, no entanto, espero apenas ter sido capaz de apresentar uma posição potencialmente atrativa e significativamente diferente do conjunto das interpretações disponíveis - e assim ter mostrado que Nietzsche pode ter algo distintivo e plausível para contribuir com uma questão ética central: o que constitui uma boa vida.

182 | Cad. Nietzsche, Guarulhos/Porto Seguro, v.37 n.1, p. 145-184, 2016. 


\begin{abstract}
Central to Nietzsche's perfectionism are two ideals: flourishing and excellence. This article offers an original account of what they each involve, including how they differ and connect, plus an axiological picture that makes sense of that. It also suggests that the underlying model of value which emerges - in effect, a model of a good life-is interesting and attractive in its own right, and that it may therefore have wider philosophical appeal.
\end{abstract}

Keywords: excellence - perfectionism - flourishing - value

\title{
Referências Bibliográficas
}

ANDERSON, Lanier R. "What is a Nietzschean Self?". In. JANAWAY, C. \& ROBERTSON, S. Nietzsche, Naturalism and Normativity. Oxford: Oxford University Press, 2012, p. 202-35.

CLARK, Maudemarie. "On the Rejection of Morality: Bernard Williams' Debt to Nietzsche”. In. SCHACHT, R. (Org.). Nietzsche's Postmoralism Cambridge: Cambridge University Press, 2001, p. 100-122.

GEMES, Ken. "Freud and Nietzsche on Sublimation". In. Journal of Nietzsche Studies 38 (1), 2009, p. 38-59.

HURKA, Thomas. "Nietzsche: Perfectionist". In. LEITER, B. \& SINHABABU, N. Nietzsche and Morality, ed.. Oxford: Clarendon Press, 2007, p. 9-31.

JANAWAY, Christopher. "Nietzsche on Morality, Drives, and Human Greatness". In. JANAWAY, C. \& ROBERTSON, S. (Org.). Nietzsche, Naturalism and Normativity. Oxford: Oxford University Press, 2012, p. 183-201.

KATSAFANAS, Paul. Agency and the Foundations of Ethics: Nietzschean Constitutivism. Oxford: Oxford University Press, 2013.

KORSGAARD, Christine: 'Two Distinctions in Goodness'. In. Philosophical Review 92, 1983, p.169-95.

LEITER, Brian. “Nietzsche's Metaethics: Against the privilege Readings. In. European Journal of Philosophy 8 (3), 2000, p. 277-297.

. Nietzsche on Morality. London: Routledge, 2002. 
Robertson, R.

OWEN, David. Nietzsche's Genealogy of Morality. Acumen Press, 2007.

MCMAHAN, Jeff. "Death and the Value of Life". In. Ethics 99/1, 1988, p. 32-61.

NIETZSCHE, F. Sämtliche Werke Kritische Studienausgabe. In. 15 Bänden, herausgegeben von G. Colli \& M Montinari. B erlin: Walter de Gruyter, 1967-77.

PARFIT, Derek. Reasons and Persons. Oxford: Oxford University Press, 1984.

PIPPIN, Robert. Nietzsche, Psychology, \& First Philosophy. Chicago: Chicago University Press, 2010.

REGINSTER, Bernard. "The Will to Power and the Ethics of Creativity". In. LEITER, B. \& SINHABABU, N. (Org.) Nietzsche and Morality. Oxford: Clarendon Press, 2007, p. 32-56.

RICHARDSON, John. Nietzsche’s system. Oxford: Oxford University Press, 1996.

RIDLEY, Aaron. "Nietzsche's Intentions: What the Sovereign Individual Promises". In. K. GEMES \& S. MAY (Org.). Nietzsche on Freedom and Autonomy. Oxford: Oxford University Press, 2009.

ROBERTSON, Simon. "Nietzsche's Ethical Revaluation". In. Journal of Nietzsche Studies (37), 2009, 66-90.

. "Normativity for Nietzschean Free Spirits". In. Inquiry 54(6), 2011, p. 591-613.

. Nietzsche \& Contemporary Ethics. Oxford University Press (no prelo).

SCANLON, T.M. What we owe to each other. Cambridge, Massachusetts: Belknap Press of Harvard University Press, 1998.

THOMAS, Alan. "Nietzsche and Moral Fictionalism". In. JANAWAY, C. \& ROBERTSON, S. Nietzsche, Naturalism and Normativity. Oxford: Oxford University Press, 2012, p.133-59.

VELLEMAN, David. The Possibility of Practical Reason. Oxford: Oxford University Press, 2000.

Artigo recebido para publicação em 06/08/2015.

Artigo aceito para publicação em 18/11/2015.

184 Cad. Nietzsche, Guarulhos/Porto Seguro, v.37 n.1, p. 145-184, 2016. 